\title{
Preface: Introduction of IGCP 649 Project- Diamonds and Recycled Mantle
}

\author{
Jingsui Yang ${ }^{*}$, Tingting Shen, Cong Zhang, Tian Qiu \\ Key Laboratory of Deep-Earth Dynamics of Ministry of Natural Resources, Institute of Geology, \\ Chinese Academy of Geological Sciences, Beijing 100037, China \\ (iD) Jingsui Yang: https://orcid.org/0000-0003-0250-4475
}

This special issue is attributed to the IGCP-649 Project. The IGCP-649 Project "Diamonds and Recycled Mantle" is an International Geosciences Program sponsored by UNESCO (the United Nations Educational, Scientific and Cultural Organization) and IUGS (International Union of Geological Sciences), is a global research project, aimed to carry out extensive and systematic research on peridotites, chromitites and related ma-terials such as diamond, moissanite and other unusual minerals, from different ophiolites in global orogenic belts, in order to understand the formation and origin of deep-mantle minerals in oceanic lithosphere, the origin of carbon for the ophiolitehosted diamonds, the evolution of Earth's mantle and the dy-namic process of ophiolite emplacement. The IGCP-649 project (2015-2020), undertaken by the Center for Advanced Research on the Mantle (CARMA), leading by Prof. Jingsui Yang, Insti-tute of Geology, Chinese Academy of Geological Sciences (CAGS), Beijing, China.

Ophiolites are 5 to $10 \mathrm{~km}$-thick fragments of ancient ocean lithosphere emplaced on continental margins, and provide 3-dimensional exposures to examine the internal structure, chemical makeup and the processes of formation of oceanic rocks (Dilek and Furnes, 2011). They are also essential for containing ore bodies, such as chromites, gold and platinum group minerals, and copper deposits as valuable commodities. Conventional models interpret ophiolites as manifestations of partial melting of the upper mantle at shallow depths $(60-80 \mathrm{~km})$. Podiform chromitites in ophioltes are thought as magmatic deposits formed due to melt-rock reactions beneath seafloor spreading centers (Arai, 1997; Zhou et al., 1994). However, recent discoveries of in-situ diamonds and other ultrahigh pressure (UHP) minerals, highly reduced phases, native elements, and crustal minerals in ophiolitic peridotites-chromitites of southern Tibet, northern Russia and Burma, suggest that these bodies form at mantle depths of 150-300 $\mathrm{km}$ or perhaps deeper, near the mantle transition zone (Yang et al., 2015, 2007; Dobrzhinetskaya et al., 2009; Trumbull et al., 2009; Bai et al., 2003). These ophiolitic diamonds are distinctly different in their morphology, carbon isotopes and mineral inclusions from diamonds occurring in kimberlites and UHP metamorphic belts, indicating a new environment for diamond formation and carbon reservoir in the deep

*Corresponding author: yangjsui@163.com

(C) China University of Geosciences (Wuhan) and Springer-Verlag

GmbH Germany, Part of Springer Nature 2019 mantle. The widely accepted models for the formation of podiform chromitites propose their precipitation from melt-rock reactions between tholeiitic to boninitic magmas and their host peridotites, which commonly consist of depleted harzburgites in mantle wedges at $60-80 \mathrm{~km}$ at depth. These models infer that during melt-rock reactions both clinopyroxene and orthopyroxene are removed, leaving behind a residuum of dunite, enveloping the chromitite bodies (Dilek and Morishita, 2009; Arai, 1997; Zhou et al., 1994). Although interpreting some of the field observations and geochemical features in peridotites and associated chromitites adequately, these models do not provide a plausible explanation for the existence in these ultramafic rock suites of diamonds and other UHP minerals that clearly originated near the transition zone in the mantle. The Project IGCP649 undertook systematic sampling of peridotites-chromitites in different ophiolites with diverse ranges of ages and geochemical affinities, such as ophiolite in China, Cyprus, Cuba and New Caledonia, to document the extent of diamond occurrence in the mantle.

Until now, four IGCP-649 ophiolite workshops have been held around the world for researchers working on ophiolites and chromitites to study and communicate with each other and also provide opportunities for geologists to investigate the composition and evolution of the deep oceanic mantle by studying ophiolites in different orogenic belts. The 1st Ophiolite Workshop was held in Xining of Qinghai Province, China, in August of 2015. After the workshop, participants undertook a field trip to investigate the Early Paleozoic ophiolite and high-pressure metamorphic belt in the Qilian Mountain. For the second workshop in 2016, the organizers chose world famous Tethyan Troodos ophiolite in Cyprus to have a 4-day profile across the complete ophiolite sequence and examine the lithological and compositional variations within the Cretaceous oceanic crust (Yang et al., 2016). The third 2017 IGCP-649 workshop took place in Havana, the capital of Cuba and a UNESCO World Heritage Site, to investigate and discuss the origin of Cuba ophiolite, chromitites, and peri-Caribbean mantle dynamics during VII Cuba Earth Science Convention. The world-famous Mayarí-Baracoa ophiolite belt (MBOB) in northeastern Cuba is the best preserved oceanic lithosphere from the pre-Eocene Cuban orogeny (Yang et al., 2017). The fourth workshop was held on July 4-15, in Brisbane (Australia) and New Caledonia. The workshop was led by Prof. Jingsui Yang from Institute of Geology, CAGS, China, and Prof. Jonathan Aitchison from School of Earth and Environment Sciences, The University of Queensland, Australia (Yang and Shen, 
2018). After the workshop, attendees participated in a field trip to New Caledonia. New Caledonia is a French Overseas Territory, located in the Southwest Pacific, about $1200 \mathrm{~km}$ east of Queensland. New Caledonia consists of a principal island - Grande Terre, which is continental in origin, the Loyalty Islands, which are oceanic origin, a number of small, isolated islands that are geologically young, and several reefs. New Caledonia separated from Australia about $85 \mathrm{Ma}$ ago, and drifted to the northeast and reaching its present position about $55 \mathrm{Ma}$ ago. During the Cenozoic, large parts of New Caledonia experienced a series of marine transgressions, and by the Late Eocene nearly all of the island was covered by a thick $(2000 \mathrm{~km})$ sheet of peridotite that was slowly over-thrust during tectonic movement. The extensive dissected nappe of ultramafic rocks, the New Caledonia Peridotite Nappe, is one of the largest exposed ultramafic bodies on Earth, and once they extended across nearly all the of the Grande Terre as well as Pines Island and Belep Islands. Although has been reduced by erosion, but it still covers $41 \%$ of the archipelago, and contributed to the considerable economic $\mathrm{Ni}$, $\mathrm{Co}$ and $\mathrm{Cr}$ resources (Pirard et al., 2013). The famous blueschist to eclogite facies rocks, which crop out in the NE of the island are inferred to have experienced high-P metamorphism in response to the attempted subduction of the crustal basement terranes of New Caledonia beneath the Eocene oceanic island-arc subduction system (Clarke et al., 1997). During the field trip, various kinds of peridotites and serpentinites, chromitites, basalts, boninites, blueschist eclogites and rocks with fossils were investigated in detail and many samples were collected. Large amounts of peridotites and chromitites were collected for future mineral separation, petrological and geochemical studies. This year, which also the last year of IGCP649 project, the organizers plan to visit the world most famous ophiolite-Oman ophiolite. The workshop and field trip will take place on November 12-22, 2019, at Sultan Qaboos University in Oman, to investigate the world famous Semail ophiolite sequence (including crustal sequence, mantle sequence and the "Moho" section), chromitite (Nakhl area), and related high-pressure metamorphic rocks (blueschists, eclogites, marbles and politic schists in Sifah area) in southwest of Muscat, Oman. Hope this workshop will provide professors, experts, students more opportunity to discuss some of the most significant scientific questions pertaining to the mantle dynamics and composition.

The final publication is available at Springer via https://doi.org/10.1007/s12583-019-1229-6.

\section{REFERENCES CITED}

Arai, S., 1997. Origin of Podiform Chromitites. Journal of Asian Earth Sciences,
15(2/3): 303-310. https://doi.org/10.1016/s0743-9547(97)00015-9

Bai, W. J., Yang, J. S., Fang, Q. S., et al., 2003. An Unusual Mantle Mineral Group in Ophiolites of Tibet. Geology in China, 30(2): 144-150 (in Chinese with English Abstract)

Clarke, G. L., Aitchison, J. C., Cluzel, D., 1997. Eclogites and Blueschists of the Pam Peninsula, NE New Caledonia: A Reappraisal. Journal of Petrology, 38(7): 843-876. https://doi.org/10.1093/petroj/38.7.843

Dilek, Y., Morishita, T., 2009. Melt Migration and Upper Mantle Evolution during Incipient Arc Construction: Jurassic Eastern Mirdita Ophiolite, Albania. Island Arc, 18(4): 551-554. https://doi.org/10.1111/j.1440-1738.2009.00692.x

Dilek, Y., Furnes, H., 2011. Ophiolite Genesis and Global Tectonics: Geochemical and Tectonic Fingerprinting of Ancient Oceanic Lithosphere. Geological Society of America Bulletin, 123(3/4): 387-411. https://doi.org/10.1130/b30446.1

Dobrzhinetskaya, L. F., Wirth, R., Yang, J. S., et al., 2009. High-Pressure Highly Reduced Nitrides and Oxides from Chromitite of a Tibetan Ophiolite. Proceedings of the National Academy of Sciences, 106(46): 19233-19238. https://doi.org/10.1073/pnas.0905514106

Pirard, C., Hermann, J., O’Neill, H. S. C., 2013. Petrology and Geochemistry of the Crust-Mantle Boundary in a Nascent Arc, Massif Du Sud Ophiolite, New Caledonia, SW Pacific. Journal of Petrology, 54(9): 1759-1792. https://doi.org/10.1093/petrology/egt030

Trumbull, R. B., Yang, J. S., Robinson, P. T., et al., 2009. The Carbon Isotope Composition of Natural SiC (moissanite) from the Earth's Mantle: New Discoveries from Ophiolites. Lithos, 113(3/4): 612-620. https://doi.org/10.1016/j.lithos.2009.06.033

Yang, J. S., Dobrzhinetskaya, L., Bai, W. J., et al., 2007. Diamond- and Coesite-Bearing Chromitites from the Luobusa Ophiolite, Tibet. Geology, 35(10): 875-878. https://doi.org/10.1130/g23766a.1

Yang, J. S., Meng, F. C., Xu, X. Z., et al., 2015. Diamonds, Native Elements and Metal Alloys from Chromitites of the Ray-Iz Ophiolite of the Polar Urals. Gondwana Research, 27(2): 459-485. https://doi.org/10.1016/j.gr.2014.07.004

Yang, J. S., Pearce, J., Dilek, Y., 2016. Probing the Troodos Ophiolite: IGCP-649 Workshop and Field Excursion Held in Agros-Cyprus. Acta Geologica Sinica-English Edition, 90(3): 1041-1044. https://doi.org/10.1111/1755-6724.12744

Yang, J. S., Qiu, T., Angelica, I. L. C., 2017. Report on the Third IGCP-649 International Workshop on the Mayarí-Baracoa Ophiolites and Chromitites, Cuba. Acta Geologica Sinica-English Edition, 91(6): 2305-2309. https://doi.org/10.1111/1755-6724.13466

Yang, J. S., Shen, T. T., 2018. IGCP-649 Project Held 2018 International Workshop and Field Trip in Brisbane, Australia and New Caledonia. Episodes, 41(4): 259-265

Zhou, M. F., Robinson, P. T., Bai, W. J., 1994. Formation of Podiform Chromitites by Melt/Rock Interaction in the Upper Mantle. Mineralium Deposita, 29(1): 98-101. https://doi.org/10.1007/bf03326400 